\title{
Effects of straw mulching on maize photosynthetic characteristics and rhizosphere soil micro-ecological environment
}

\author{
Xiangqian Zhang ${ }^{1}$, Yiliang Qian², and Chengfu Cao ${ }^{1 *}$
}

\begin{abstract}
Straw mulching is an effective measure to improve soil properties, crop growth, and yield. To further understand the advantage mechanisms of straw mulching, a field experiment with seven straw mulching levels $\left(0\right.$ to $\left.18000 \mathrm{~kg} \mathrm{ha}^{-1}\right)$ was conducted to study the effects of straw mulching on maize (Zea mays L.) photosynthesis and rhizosphere soil microecological environment. Results showed that maize chlorophyll content was evidently affected by straw mulching, and the highest chlorophyll content was at $12000 \mathrm{~kg} \mathrm{ha}^{-1}$ (M4). Straw mulching could significantly improve the photosynthetic characteristics of maize, and the difference between M4 and $0 \mathrm{~kg} \mathrm{ha}^{-1}(\mathrm{M} 0)$ was significant. There was as trend change in soil microbe quantity; it first increased and then decreased with increasing straw mulching levels, and the most suitable straw mulching level for different types of microorganisms was $9000 \mathrm{~kg} \mathrm{ha}^{-1}$ (M3) or M4. Straw mulching significantly enhanced soil enzyme urease, invertase, dehydrogenase, and protease activities, but when the straw mulching level reached a certain level, the effect of straw mulching was no longer apparent and even had some adverse effects at straw mulching levels higher than $15000 \mathrm{~kg} \mathrm{ha}^{-1}$ (M5). Yield in M4 (10 $186.84 \mathrm{~kg} \mathrm{ha}^{-1}$ ) was the highest compared with M0 (9365.12 kg ha-1), and yield significantly increased by $8.8 \%$. Correlation analyses indicated that the soil microbe quantity and aforementioned enzyme activities were all significantly and positively correlated with maize chlorophyll content, photosynthetic rate, and yield. Findings suggest that straw mulching can apparently increase soil microbe quantity and enzyme activities and improve crop photosynthesis and yield; the M4 level is the most reasonable straw mulching level in this study under comprehensive consideration, and a straw mulching level that is too high (over M5) will have some negative effects.
\end{abstract}

Key words: Chlorophyll content, enzyme activities, microbe quantity, photosynthesis, yield, Zea mays.

\section{INTRODUCTION}

The practice of straw mulching has been widely used as an important management tool in many parts of the world (Ghosh et al., 2006). Straw mulching has many advantageous effects when compared with no mulching. It dampens the influence of environmental factors on soil by increasing soil temperature and controlling diurnal/seasonal fluctuations in soil temperature (Novak et al., 2000; Li et al., 2013). It also enhances the soil biotic activity of earthworms (Lal, 2000) and other soil fauna, and improves, to a certain extent, soil structure and quality (Döring et al., 2005; Govaerts et al., 2007). Because of this, many related research studies on straw mulching have been done by agronomists worldwide and

${ }^{1}$ Crops Research Institute, Anhui Academy of Agricultural Sciences, Hefei, Anhui Province, 230031, P.R. China.

*Corresponding author (caocfu@126.com).

${ }^{2}$ Tobacco Research Institute \& Maize Research Centre, Anhui Academy of Agricultural Sciences, Hefei, Anhui Province, 230031, P.R. China.

Received: 30 November 2014.

Accepted: 11 July 2015.

doi: $10.4067 / \mathrm{S} 0718-58392015000500014$ have obtained many valuable results. Previous studies mainly focus on soil temperature, moisture, bulk density, small animals, nutrient status, chemical properties, crop seedling emergency, diseases and pests, and growth and development However, research is relatively scarce on crop photosynthetic characteristics, especially on soil microbe quantity and enzyme activities, which seem to be strongly affected by the agricultural measures of straw mulching in farmland systems.

It is well known that chlorophyll is the basic material for plant photosynthesis and its levels determine, to a certain extent, the photosynthetic rate (Zhang et al., 2013). The improvement of leaf photosynthetic characteristics has a significant impact on crop growth and development, dry matter accumulation, and final grain yield formation (Anten, 2005; Makino, 2011). Soil microbes are a diverse group of microorganisms that are multifunctional and involved in many important ecosystem processes, including biogeochemical cycling (Anderson et al., 2011; Zhang et al., 2013), nutrient acquisition (Smith and Read, 2008), and soil aggregation (Rillig and Mummey, 2006). They can strongly influence plant productivity by directly or indirectly affecting it (Van der Heijden et al., 2008). Soil enzymes are primarily derived from microorganisms, 
plant roots. and soil animals; they participate in specific types of chemical reactions in soils (Tan et al., 2008) and are also potential indicators of soil biological activity and fertility (Caldwell, 2005). Due to photosynthesis and soil micro-ecological environment not only play an important role in improving crop yield and soil quality and are also apparently affected by straw mulching, we studied the effects of straw mulching on maize (Zea mays L.) chlorophyll content, photosynthetic characteristics, yield, soil microbe quantity, and enzyme activities. The objectives were (i) to clarify the trend change in maize chlorophyll content, photosynthetic characteristics, yield, soil microbe quantity, and enzyme activities with increasing straw mulching levels; (ii) to elucidate the correlations between the soil micro-ecological environment and chlorophyll content, photosynthetic rate, and yield; and (iii) to identify the advantageous mechanisms of straw mulching and the underlying cause of different effects among different straw mulching levels. We hypothesized that the most suitable straw mulching levels for maize chlorophyll content, photosynthetic characteristics, yield, and rhizosphere soil microbe quantity and enzyme activities were different and higher straw mulching levels would produce some adverse effects.

\section{MATERIALS AND METHODS}

\section{Experimental design and management}

The field experiment was conducted in 2013 and 2014 at the Lime Concretion Black Soil Experimental Station of Anhui Academy of Agricultural Sciences, Huaibei City (335' N, 116 54' E; 29.0 m a.s.1.), Anhui Province, China. The annual mean temperature is 14 to $16^{\circ} \mathrm{C}$ and accumulated temperatures above $10{ }^{\circ} \mathrm{C}$ were 4300 to $4800{ }^{\circ} \mathrm{C}$. Annual mean precipitation is 750 to $850 \mathrm{~mm}$. The region is classified as a warm, semi-humid, and semi-dry monsoon climate. The experimental soil is lime concretion black soil, Orthic Acrisol (FAO-UNESCO system) derived from loess soil of Furukawa sediments (river and lake sediments during the Cenozoic-Quaternary rich in $\left.\mathrm{CaCO}_{3}\right)$ with a sandy loam texture $(57 \%$ sand, $18 \%$ silt, and $25 \%$ clay). The experimental soil had $\mathrm{pH}$ of 7.6, organic matter of $10.1 \mathrm{~g} \mathrm{~kg}^{-1}$, total $\mathrm{N}$ of $0.53 \mathrm{~g} \mathrm{~kg}^{-1}$, total $\mathrm{P}$ of $0.41 \mathrm{~g} \mathrm{~kg}^{-1}$, available $\mathrm{N}$ of $45.2 \mathrm{mg} \mathrm{kg}^{-1}$, available $\mathrm{P}$ of $11.3 \mathrm{mg} \mathrm{kg}^{-1}$, available $\mathrm{K}$ of $110.5 \mathrm{mg} \mathrm{kg}^{-1}$, and soil water capacity of $18.7 \%$.

The field experiment was conducted as a randomized block design with seven straw mulching levels as the treatment variables. There were seven treatments in this experiment and each treatment was replicated three times. The seven straw mulching levels were $0 \mathrm{~kg} \mathrm{ha}^{-1}(\mathrm{M} 0)$, $3000 \mathrm{~kg} \mathrm{ha}^{-1}$ (M1), $6000 \mathrm{~kg} \mathrm{ha}^{-1}$ (M2), $9000 \mathrm{~kg} \mathrm{ha}^{-1}$ (M3), $12000 \mathrm{~kg} \mathrm{ha}^{-1}$ (M4), $15000 \mathrm{~kg} \mathrm{ha}^{-1}$ (M5), and 18000 $\mathrm{kg} \mathrm{ha}^{-1}$ (M6). During the summer maize five-leaf stage, straw mulching was carried out by applying winter wheat straw that was chopped into approximately 10 to $15 \mathrm{~cm}$ pieces. All plots received a basal application of $200 \mathrm{~kg} \mathrm{~N}$ $\mathrm{ha}^{-1}, 200 \mathrm{~kg} \mathrm{P} \mathrm{ha}^{-1}$, and $150 \mathrm{~kg} \mathrm{~K} \mathrm{ha}^{-1}$. All fertilizers were evenly broadcast and incorporated into the soil $(0-20 \mathrm{~cm})$ prior to sowing. At the maize bell-mouthed stage, $150 \mathrm{~kg}$ $\mathrm{N} \mathrm{ha}^{-1}$ was applied as topdressing. Nitrogen was supplied as urea and $\left(\mathrm{NH}_{4}\right)_{2} \mathrm{HPO}_{4}$, while $\mathrm{P}$ and $\mathrm{K}$ were applied as $\left(\mathrm{NH}_{4}\right)_{2} \mathrm{HPO}_{4}$ and $\mathrm{K}_{2} \mathrm{SO}_{4}$, respectively. Each experimental plot area was $24.0 \mathrm{~m}^{2}(3 \mathrm{~m} \times 8 \mathrm{~m})$ with row spacing of $60 \mathrm{~cm}$ between the two neighboring plots. 'Zhengdan958' (a local variety) maize was sown on 5 June and was harvested on 7 October. Plant spacing and row spacing for maize were 30 and $40 \mathrm{~cm}$, respectively.

\section{Sampling and measurements}

Chlorophyll content: A hand-held chlorophyll meter (SPAD-502, Konica Minolta Company, Tokyo, Japan, measuring area of $2 \mathrm{~mm} \times 3 \mathrm{~mm}$ ) was used to measure chlorophyll content. The same leaf parts in the middle of the maize plants were selected and analyzed at the bellmouthed, silking, filling, and maturity stages.

Photosynthetic characteristics: A portable photosynthesis system (LI-6400, LI-COR, Lincoln, Nebraska, USA) was used to measure leaf photosynthetic rate, stomatal conductance, intercellular $\mathrm{CO}_{2}$ concentration, and transpiration rate. Maize ear leaves were selected for leaf measurements and each leaf was evaluated in five points. Measurements were performed from 10:00 to $11: 30 \mathrm{~h}$ local time at the silking and filling stages.

Microbe quantity: The number of soil bacteria, actinomycetes, fungi, and Azotobacter was measured at the silking and filling stages. Soil cores near the maize roots were sampled with an auger. The top $1 \mathrm{~cm}$ soil layer was removed and the remaining soil core (as deep as 20 $\mathrm{cm}$ ) was collected as a sample. Soil samples were air-dried and sieved with a 1-mm sieve. Ten grams of each fresh soil sample was added to $95 \mathrm{~mL}$ sterile distilled water. Each soil suspension was homogenized for $30 \mathrm{~min}$, sequentially diluted, and $50 \mu \mathrm{L}$ of the resulting solutions were plated on appropriate isolation culture media. Colony forming units (CFU) were counted after incubation at $28{ }^{\circ} \mathrm{C}$ for 5-6 d for bacteria, 6-8 d for actinomycetes, 4-5 d for fungi, or 6-7 d for Azotobacter. Maize rhizosphere soil bacteria, actinomycetes, fungi, and Azotobacter were cultured on beef extract + peptone + agar medium, improved Gauss nr 1 medium, Martin medium, and Waksman nr 77 medium (Vieira and Nahas, 2005), respectively.

Soil enzyme activities: Soil urease, invertase, dehydrogenase, and protease activities were measured in air-dried soils according to the method by Guan et al. (1986) with a spectrophotometer (722s, Shanghai Precision \& Scientific Instrument, Shanghai, China). Urease activity was measured colorimetrically with indophenol blue and expressed in $\mathrm{mg} \mathrm{NH}_{3}-\mathrm{N} \mathrm{g}^{-1}$ soil at $37{ }^{\circ} \mathrm{C}$ for $24 \mathrm{~h}$. Invertase activity was determined colorimetrically with 3,5-dinitrosalicylic acid and 
expressed in mg glucose $\mathrm{g}^{-1}$ soil at $37{ }^{\circ} \mathrm{C}$ for $24 \mathrm{~h}$. Dehydrogenase activity was determined colorimetrically with 2,3,5-triphenyltetrazolium chloride (TTC) and expressed as $\mu \mathrm{g}$ 1,3,5-triphenylformazan (TPF) released $\mathrm{g}^{-1}$ soil after incubation at $30^{\circ} \mathrm{C}$ for $24 \mathrm{~h}$. Protease activity was determined colorimetrically with ninhydrin and expressed as $\mu \mathrm{g} \mathrm{NH}_{2}$ produced $\mathrm{g}^{-1}$ soil after incubation at $50{ }^{\circ} \mathrm{C}$ for $2 \mathrm{~h}$.

\section{Statistical analysis}

The experiment was conducted as a randomized block design with seven straw mulching levels as the treatment variable. The ANOVA was performed by the general linear model-univariate procedure from the SPSS 17.0 software (Softonic International, Barcelona, Spain). The ANOVAs were performed with the straw mulching level as the main effect. All treatment means were compared for any significant differences by the LSD multiple range tests at the $P=0.05$ significance level. Correlation analyses were also performed to evaluate the degree and significance of the correlation. The study data was the mean of $2 \mathrm{yr}$ of experimental results (the statistical analysis showed no significant differences between the $2 \mathrm{yr}$ of experimental results).

\section{RESULTS}

\section{Chlorophyll content of maize at different growth stages}

In the same growth stage (Table 1), there was a trend change in chlorophyll content of maize ; it first increased and then decreased with increasing straw mulching levels, and chlorophyll content in the M4 mulching treatment was the highest followed by M3. Compared with the M0 and M6 treatments, the M4 treatment increased chlorophyll content by $8.0 \%, 11.6 \%, 10.4 \%$, $12.2 \%$ and $3.0 \%, 2.3 \%, 3.6 \%, 2.1 \%$ at the bell-mouthed, silking, filling, and maturity stages, respectively; the difference between M4 and M0 was significant, while it was not significant between M4 and M6. There was no significant difference among treatments M2, M3, M4, M5, and M6, but they all had significant differences with M0 (Table 1). The analysis indicated that straw mulching could significantly increase chlorophyll

Table 1. Effects of different straw mulching levels on maize chlorophyll content at different growth stages (SPAD values).

\begin{tabular}{lllll}
\hline $\begin{array}{l}\text { Mulching } \\
\text { treatment } \\
\left(\mathrm{kg} \mathrm{ha}^{-1}\right)\end{array}$ & $\begin{array}{c}\text { Bell- } \\
\text { mouthed } \\
\text { stage }\end{array}$ & $\begin{array}{c}\text { Silking } \\
\text { stage }\end{array}$ & \multicolumn{1}{c}{$\begin{array}{c}\text { Filling } \\
\text { stage }\end{array}$} & $\begin{array}{c}\text { Maturity } \\
\text { stage }\end{array}$ \\
\hline M0: 0 & $48.56 \pm 1.38 \mathrm{c}$ & $52.22 \pm 2.27 \mathrm{c}$ & $49.68 \pm 1.76 \mathrm{c}$ & $41.14 \pm 1.72 \mathrm{c}$ \\
M1: 3000 & $49.44 \pm 1.58 \mathrm{bc}$ & $55.26 \pm 2.31 \mathrm{~b}$ & $51.90 \pm 1.45 \mathrm{~b}$ & $43.58 \pm 2.10 \mathrm{~b}$ \\
M2: 6000 & $50.84 \pm 2.09 \mathrm{ab}$ & $56.70 \pm 1.58 \mathrm{ab}$ & $53.62 \pm 1.93 \mathrm{ab}$ & $45.48 \pm 0.77 \mathrm{ab}$ \\
M3: 9000 & $52.18 \pm 1.64 \mathrm{a}$ & $57.64 \pm 2.62 \mathrm{ab}$ & $54.30 \pm 1.57 \mathrm{a}$ & $45.96 \pm 2.04 \mathrm{a}$ \\
M4: 12000 & $52.44 \pm 1.63 \mathrm{a}$ & $58.28 \pm 2.07 \mathrm{a}$ & $54.86 \pm 1.40 \mathrm{a}$ & $46.14 \pm 1.72 \mathrm{a}$ \\
M5: 15000 & $51.54 \pm 1.22 \mathrm{ab}$ & $57.16 \pm 2.31 \mathrm{ab}$ & $53.88 \pm 1.22 \mathrm{ab}$ & $45.86 \pm 1.49 \mathrm{a}$ \\
M6: 18000 & $50.90 \pm 1.68 \mathrm{ab}$ & $56.96 \pm 2.29 \mathrm{ab}$ & $52.94 \pm 1.51 \mathrm{ab}$ & $45.18 \pm 1.26 \mathrm{ab}$
\end{tabular}

Values are means $\pm \mathrm{SD}(\mathrm{n}=5)$. Means followed by different letters in the same column indicate a significant difference $(P<0.05)$. content of maize when compared with the no mulching treatment, but when the straw mulching level increased to a certain level, its effect was no longer significant, and even tended to decrease.

\section{Photosynthetic characteristics of maize}

There was a trend change in photosynthetic rate, stomatal conductance, and transpiration rate of maize at the silking and filling stages; these first increased and then decreased with increasing straw mulching levels, and values for M0 (no mulching) were the lowest, and the highest for M4 (Table 2). Compared with the M0 and M6 treatments, M4 increased photosynthetic rate, stomatal conductance, and transpiration rate by $22.9 \%, 54.5 \%, 21.1 \%$ and $8.8 \%, 14.4 \%, 6.4 \%$ at the silking stage, and by $30.3 \%$, $70.1 \%, 17.2 \%$ and $10.2 \%, 18.8 \%, 5.5 \%$ at the filling stage, respectively, and the difference between M4 and M0 was significant. The intercellular $\mathrm{CO}_{2}$ concentration of maize leaf at the silking and filling stages exhibited a trend change; it first decreased and then increased with increasing straw mulching levels, and the value for M0 was the highest when compared with M2, M3, M4, M5, and M6. Intercellular $\mathrm{CO}_{2}$ concentrations (M2 to M6) significantly increased by $14.0 \%, 20.6 \%, 24.2 \%, 16.5 \%$, $15.1 \%$ and $8.6 \%, 13.1 \%, 16.1 \%, 11.2 \%, 7.4 \%$ at the silking stage and filling stage, respectively. Therefore, appropriately increasing straw mulching levels can significantly improve the photosynthetic characteristics of maize, but when the straw mulching level is too high, it will negatively influence the improvement of photosynthetic characteristics.

\section{Microbe quantity in maize rhizosphere soil}

The number of bacteria and total microbe quantity in the soil were the highest in the M3 treatment, the number of fungi and Azotobacter were the highest in the M4 treatment, the number of actinomycetes was the highest in

Table 2. Effects of different straw mulching levels on photosynthetic characteristics of maize at the silking and filling stages.

\begin{tabular}{|c|c|c|c|c|}
\hline $\begin{array}{l}\text { Mulching } \\
\text { treatment }\end{array}$ & $\begin{array}{l}\text { Photosynthetic } \\
\text { rate }\end{array}$ & $\begin{array}{c}\text { Stomatal } \\
\text { conductance }\end{array}$ & $\begin{array}{c}\text { Intercellular } \\
\mathrm{CO}_{2} \\
\text { concentration }\end{array}$ & $\begin{array}{c}\text { Transpiration } \\
\text { rate }\end{array}$ \\
\hline$\left(\mathrm{kg} \mathrm{ha}^{-1}\right)$ & $\mu \mathrm{mol} \mathrm{m}^{-2} \mathrm{~s}^{-1}$ & $\mathrm{~mol} \mathrm{~m}^{-2} \mathrm{~s}^{-1}$ & $\mu \mathrm{mol} \mathrm{mol}^{-1}$ & $\mathrm{mmol} \mathrm{m}^{-2} \mathrm{~s}^{-1}$ \\
\hline \multicolumn{5}{|l|}{ Silking stage } \\
\hline M0: 0 & $18.53 \pm 1.49 b$ & $0.400 \pm 0.04 \mathrm{e}$ & $269.48 \pm 15.54 \mathrm{a}$ & $2.32 \pm 0.25 c$ \\
\hline M1: 3000 & $20.46 \pm 1.48 \mathrm{ab}$ & $0.474 \pm 0.03 \mathrm{~d}$ & $249.18 \pm 16.34 b$ & $2.53 \pm 0.18 b c$ \\
\hline M2: 6000 & $21.40 \pm 2.19 \mathrm{a}$ & $0.536 \pm 0.03 \mathrm{c}$ & $236.44 \pm 11.61 b c$ & $2.65 \pm 0.21 \mathrm{ab}$ \\
\hline M3: 9000 & $21.90 \pm 2.79 \mathrm{a}$ & $0.586 \pm 0.03 \mathrm{ab}$ & $223.40 \pm 12.40 \mathrm{~cd}$ & $2.76 \pm 0.27 \mathrm{ab}$ \\
\hline M4: 12000 & $22.78 \pm 2.44 a$ & $0.618 \pm 0.06 a$ & $217.00 \pm 14.40 \mathrm{~d}$ & $2.81 \pm 0.29 a$ \\
\hline M5: 15000 & $21.70 \pm 2.41 \mathrm{a}$ & $0.578 \pm 0.05 \mathrm{abc}$ & $231.28 \pm 17.31 \mathrm{bcd}$ & d $2.70 \pm 0.29 a b$ \\
\hline M6: 18000 & $20.94 \pm 2.00 \mathrm{ab}$ & $0.540 \pm 0.04 b c$ & $234.14 \pm 14.72 \mathrm{bcd}$ & d $2.64 \pm 0.16 a b$ \\
\hline \multicolumn{5}{|l|}{ Filling stage } \\
\hline M0: 0 & $14.54 \pm 2.18 \mathrm{c}$ & $0.268 \pm 0.02 \mathrm{~d}$ & $325.42 \pm 15.02 \mathrm{a}$ & $1.98 \pm 0.16 c$ \\
\hline M1: 3000 & $16.40 \pm 1.43 b c$ & $0.338 \pm 0.02 \mathrm{c}$ & $313.62 \pm 14.09 \mathrm{ab}$ & $2.12 \pm 0.12 b c$ \\
\hline M2: 6000 & $17.76 \pm 1.78 \mathrm{ab}$ & $0.386 \pm 0.03 b$ & $299.52 \pm 11.43 \mathrm{bcd}$ & $2.22 \pm 0.12 \mathrm{ab}$ \\
\hline M3: 9000 & $18.36 \pm 2.43 \mathrm{ab}$ & $0.424 \pm 0.04 \mathrm{ab}$ & $287.68 \pm 9.36 \mathrm{~cd}$ & $2.29 \pm 0.12 \mathrm{a}$ \\
\hline M4: 12000 & $18.94 \pm 2.05 \mathrm{a}$ & $0.456 \pm 0.03 \mathrm{a}$ & $280.34 \pm 14.85 \mathrm{~d}$ & $2.32 \pm 0.16 a$ \\
\hline M5: 15000 & $17.78 \pm 2.11 \mathrm{ab}$ & $0.408 \pm 0.03 b$ & $292.66 \pm 17.03 \mathrm{~cd}$ & $2.27 \pm 0.09 \mathrm{ab}$ \\
\hline M6: 18000 & $17.18 \pm 1.64 a b$ & $0.384 \pm 0.02 b$ & $302.96 \pm 18.10 \mathrm{bc}$ & $2.20 \pm 0.09 \mathrm{ab}$ \\
\hline
\end{tabular}

Values are means $\pm \mathrm{SD}(\mathrm{n}=5)$. Means followed by different letters in the same column indicate a significant difference $(P<0.05)$. 
M3 and M4 at the silking and filling stages, respectively. This indicates that the most suitable straw mulching level for different types of microorganisms were different (Table 3). When compared with the M0 treatment, M1 significantly increased the number of bacteria, actinomycetes, fungi, Azotobacter, and total microbe quantity in soil by $26.4 \%, 26.9 \%, 22.8 \%, 46.7 \%, 26.4 \%$, respectively, at the silking stage and $31.3 \%, 40.5 \%$, $27.2 \%, 77.5 \%, 31.6 \%$, respectively, at the filling stage; this indicates that even a lower straw mulching level can have a significant impact on soil microbe quantity. Microbe quantity in maize rhizosphere soil also had a trend change; it first increased and then decreased with increasing straw mulching levels. When compared with the M6 treatment, M4 increased the number of bacteria, actinomycetes, fungi, Azotobacter, and total microbe quantity in soil by $9.3 \%, 5.8 \%, 8.3 \%, 9.1 \%, 9.1 \%$, respectively, at the silking stage and $5.3 \%, 25.6 \%, 15.9 \%$, $31.7 \%, 6.2 \%$, respectively, at and the filling stage, and the differences between the M4 and M6 treatments were partially significant (Table 3 ). In addition, the differences among treatments M3, M4, and M5 were not significant, which indicates that the change in the straw mulching effect was no longer apparent when the straw mulching level increased to a certain level.

\section{Enzyme activities in maize rhizosphere soil}

The activity of urease in M5 was the highest when compared with the M0 and M6 treatments; M5 increased the activity of urease by $29.3 \%, 7.4 \%$ and $39.6 \%, 5.8 \%$, respectively, at the silking and filling stages, and the difference between M5 and M0 was significant (Table 4). Invertase activity in the M3 treatment was the highest when compared to M0 and M6; M3 increased invertase activity by $56.5 \%$, $8.1 \%$ and $36.7 \%, 19.1 \%$ at the silking and filling stages, respectively, and the difference between M3 and M0 was significant. The activities of dehydrogenase and protease was the highest in M4 when compared to M0 and M6; M4 increased dehydrogenase and protease activity by $31.6 \%$,
$10.6 \%$ and $14.2 \%, 4.8 \%$, respectively, at the silking stage, and by $60.7 \%, 9.8 \%$ and $18.6 \%, 4.2 \%$, respectively, at the filling stage, and the difference between M4 and M0 was significant. Soil enzyme activities also had a trend change; they increased and then decreased with increasing straw mulching levels, and the most suitable straw mulching level for the highest values of different types of enzyme activities were different (Table 4). It could be found through the analysis that the differences in soil enzyme activities among M3, M4, and M5 were not significant, while they were significant among M3, M4, M5, and M0; this indicates that the suitable straw mulching level could significantly enhance soil enzyme activities when compared with the no mulching treatment, but when the straw mulching level increased to a certain level, the effect on soil enzyme activities of changing the straw mulching level was no longer apparent.

\section{Maize yield and its components}

Ear length, ear diameter, kernels per ear, 1000-kernel weight, and yield of maize presented a trend change; they

Table 4. Effects of different straw mulching levels on enzyme activities in maize rhizosphere soil at the silking and filling stages.

\begin{tabular}{lcccc}
\hline $\begin{array}{l}\text { Mulching } \\
\text { treatment }\end{array}$ & Urease & Invertase & Dehydrogenase & \multicolumn{1}{c}{ Protease } \\
\hline $\mathrm{kg} \mathrm{ha}^{-1}$ & $\begin{array}{c}\text { mg NH} \mathrm{N} \mathrm{g}^{-1} \\
\text { soil }\end{array}$ & $\begin{array}{c}\mathrm{mg} \mathrm{glucose}^{-1} \\
\mathrm{~g}^{-1} \text { soil }\end{array}$ & $\begin{array}{c}\mu \mathrm{g} \mathrm{TPF} \mathrm{g}^{-1} \\
\text { soil }\end{array}$ & $\begin{array}{c}\mu \mathrm{NH}_{2}-\mathrm{N} \mathrm{g}^{-1} \\
\text { soil }\end{array}$ \\
Silking stage & & & & \\
M0: & $1.23 \pm 0.14 \mathrm{~b}$ & $9.43 \pm 1.42 \mathrm{~b}$ & $0.79 \pm 0.10 \mathrm{c}$ & $77.86 \pm 4.30 \mathrm{c}$ \\
M1: 3000 & $1.39 \pm 0.20 \mathrm{ab}$ & $12.20 \pm 2.48 \mathrm{ab}$ & $0.90 \pm 0.07 \mathrm{~b}$ & $83.08 \pm 4.22 \mathrm{~b}$ \\
M2: 6000 & $1.44 \pm 0.21 \mathrm{ab}$ & $13.46 \pm 1.71 \mathrm{a}$ & $0.96 \pm 0.10 \mathrm{ab}$ & $85.62 \pm 3.62 \mathrm{ab}$ \\
M3: 9000 & $1.52 \pm 0.20 \mathrm{a}$ & $14.76 \pm 1.73 \mathrm{a}$ & $1.00 \pm 0.10 \mathrm{ab}$ & $87.52 \pm 3.83 \mathrm{ab}$ \\
M4: 12000 & $1.57 \pm 0.24 \mathrm{a}$ & $14.36 \pm 2.12 \mathrm{a}$ & $1.04 \pm 0.08 \mathrm{a}$ & $88.92 \pm 3.94 \mathrm{a}$ \\
M5: 15000 & $1.59 \pm 0.21 \mathrm{a}$ & $13.86 \pm 2.42 \mathrm{a}$ & $0.98 \pm 0.08 \mathrm{ab}$ & $86.00 \pm 3.56 \mathrm{ab}$ \\
M6: 18000 & $1.48 \pm 0.18 \mathrm{ab}$ & $13.66 \pm 2.77 \mathrm{a}$ & $0.94 \pm 0.07 \mathrm{ab}$ & $84.84 \pm 2.85 \mathrm{ab}$ \\
Filling stage & & & & \\
M0: 0 & $0.91 \pm 0.05 \mathrm{~d}$ & $7.81 \pm 1.01 \mathrm{~d}$ & $0.56 \pm 0.06 \mathrm{c}$ & $65.14 \pm 4.55 \mathrm{c}$ \\
M1: 3000 & $1.03 \pm 0.08 \mathrm{c}$ & $8.35 \pm 0.54 \mathrm{~cd}$ & $0.76 \pm 0.08 \mathrm{~b}$ & $71.72 \pm 2.28 \mathrm{~b}$ \\
M2: 6000 & $1.12 \pm 0.09 \mathrm{bc}$ & $9.98 \pm 0.77 \mathrm{a}$ & $0.84 \pm 0.09 \mathrm{ab}$ & $74.40 \pm 2.32 \mathrm{ab}$ \\
M3: 9000 & $1.19 \pm 0.09 \mathrm{ab}$ & $10.68 \pm 0.53 \mathrm{a}$ & $0.88 \pm 0.08 \mathrm{a}$ & $76.72 \pm 4.83 \mathrm{a}$ \\
M4: 12000 & $1.24 \pm 0.08 \mathrm{a}$ & $9.96 \pm 0.78 \mathrm{a}$ & $0.90 \pm 0.04 \mathrm{a}$ & $77.28 \pm 4.33 \mathrm{a}$ \\
M5: 15000 & $1.27 \pm 0.09 \mathrm{a}$ & $9.74 \pm 0.95 \mathrm{ab}$ & $0.85 \pm 0.06 \mathrm{ab}$ & $75.40 \pm 3.37 \mathrm{ab}$ \\
M6: 18000 & $1.20 \pm 0.12 \mathrm{ab}$ & $8.97 \pm 0.63 \mathrm{bc}$ & $0.82 \pm 0.06 \mathrm{ab}$ & $74.20 \pm 4.35 \mathrm{ab}$ \\
\hline
\end{tabular}

Values are means $\pm \mathrm{SD}(\mathrm{n}=5)$. Means followed by different letters in the same column indicate a significant difference $(P<0.05)$.

Table 3. Effects of different straw mulching levels on microbe quantity in maize rhizosphere soil at the silking and filling stages.

\begin{tabular}{|c|c|c|c|c|c|}
\hline $\begin{array}{l}\text { Mulching } \\
\text { treatment }\end{array}$ & Bacteria & Actinomycetes & Fungi & Azotobacter & Total microbe quantity \\
\hline$\left(\mathrm{kg} \mathrm{ha}^{-1}\right)$ & $\times 10^{7} \mathrm{CFU} \mathrm{g}^{-1}$ & $\times 10^{6} \mathrm{CFU} \mathrm{g}^{-1}$ & $\times 10^{5} \mathrm{CFU} \mathrm{g}^{-1}$ & $\times 10^{5} \mathrm{CFU} \mathrm{g}^{-1}$ & $\times 10^{6} \mathrm{CFU} \mathrm{g}^{-1}$ \\
\hline \multicolumn{6}{|l|}{ Silking stage } \\
\hline M0: 0 & $25.92 \pm 2.76 \mathrm{~d}$ & $11.58 \pm 1.43 \mathrm{~d}$ & $20.28 \pm 2.50 c$ & $6.12 \pm 1.10 \mathrm{~d}$ & $272.81 \pm 28.29 c$ \\
\hline M1: 3000 & $32.76 \pm 2.82 b c$ & $14.70 \pm 0.68 c$ & $24.90 \pm 3.12 b$ & $8.98 \pm 1.22 \mathrm{c}$ & $344.79 \pm 28.01 b$ \\
\hline M2: 6000 & $34.96 \pm 1.51 \mathrm{abc}$ & $15.52 \pm 1.45 b c$ & $26.80 \pm 2.64 \mathrm{ab}$ & $10.02 \pm 0.62 b c$ & $367.80 \pm 14.92 \mathrm{ab}$ \\
\hline M3: 9000 & $36.38 \pm 1.91 \mathrm{a}$ & $16.84 \pm 1.43 \mathrm{a}$ & $27.88 \pm 2.26 \mathrm{ab}$ & $11.00 \pm 0.95 \mathrm{ab}$ & $383.43 \pm 20.34 a$ \\
\hline M4: 12000 & $35.66 \pm 1.36 \mathrm{ab}$ & $16.16 \pm 1.18 \mathrm{ab}$ & $28.46 \pm 2.67 \mathrm{a}$ & $11.52 \pm 0.82 \mathrm{a}$ & $375.61 \pm 13.92 \mathrm{a}$ \\
\hline M5: 15000 & $33.60 \pm 2.06 a b c$ & $15.60 \pm 1.41 \mathrm{abc}$ & $27.38 \pm 2.27 \mathrm{ab}$ & $10.72 \pm 1.03 \mathrm{ab}$ & $354.34 \pm 20.38 \mathrm{ab}$ \\
\hline M6: 18000 & $32.64 \pm 2.34 \mathrm{c}$ & $15.28 \pm 1.10 b c$ & $26.28 \pm 2.67 \mathrm{ab}$ & $10.56 \pm 0.87 \mathrm{ab}$ & $344.31 \pm 23.21 b$ \\
\hline \multicolumn{6}{|l|}{ Filling stage } \\
\hline M0: 0 & $17.40 \pm 1.74 \mathrm{c}$ & $6.72 \pm 1.45 \mathrm{e}$ & $11.86 \pm 2.16 \mathrm{c}$ & $3.56 \pm 1.44 \mathrm{~d}$ & $181.91 \pm 16.92 \mathrm{c}$ \\
\hline M1: 3000 & $22.84 \pm 2.60 b$ & $9.44 \pm 0.71 d$ & $15.08 \pm 2.06 b$ & $6.32 \pm 1.88 c$ & $239.35 \pm 26.13 b$ \\
\hline M2: 6000 & $24.54 \pm 3.01 \mathrm{ab}$ & $11.64 \pm 1.63 \mathrm{bc}$ & $16.38 \pm 2.49 \mathrm{ab}$ & $8.40 \pm 0.88 \mathrm{ab}$ & $258.68 \pm 30.24 \mathrm{ab}$ \\
\hline M3: 9000 & $26.74 \pm 2.16 \mathrm{a}$ & $12.74 \pm 1.59 \mathrm{ab}$ & $17.50 \pm 1.89 \mathrm{ab}$ & $9.64 \pm 1.31 \mathrm{ab}$ & $281.89 \pm 23.01 \mathrm{a}$ \\
\hline M4: 12000 & $26.22 \pm 2.47 \mathrm{a}$ & $13.46 \pm 1.11 \mathrm{a}$ & $17.92 \pm 1.57 \mathrm{a}$ & $10.22 \pm 1.98 \mathrm{a}$ & $277.45 \pm 24.93 \mathrm{a}$ \\
\hline M5: 15000 & $25.24 \pm 2.03 \mathrm{ab}$ & $12.32 \pm 1.40 \mathrm{abc}$ & $16.44 \pm 1.80 \mathrm{ab}$ & $9.36 \pm 0.79 \mathrm{ab}$ & $266.36 \pm 20.08 \mathrm{ab}$ \\
\hline M6: 18000 & $24.90 \pm 3.12 \mathrm{ab}$ & $10.72 \pm 1.05 \mathrm{~cd}$ & $15.46 \pm 2.48 \mathrm{ab}$ & $7.76 \pm 1.47 b c$ & $261.27 \pm 31.32 \mathrm{ab}$ \\
\hline
\end{tabular}

Values are means \pm SD $(n=5)$. Means followed by different letters in the same column indicate a significant difference $(P<0.05)$. 
first increased and then decreased, and the abovementioned index values were the highest in M4, and the highest yield was $10186.84 \mathrm{~kg} \mathrm{ha}^{-1}$ (Table 5). When compared with the M0 and M6 treatments, M4 increased ear length, ear diameter, kernels per ear, 1000-kernel weight, and yield by $18.4 \%, 7.1 \%, 4.0 \%, 8.9 \%, 8.8 \%$ and $8.5 \%, 3.6 \%$, $1.6 \%, 3.6 \%, 3.5 \%$, respectively. Ear length, ear diameter, kernels per ear, 1000-kernel weight, and yield in M2, M3, M4, M5, and M6 were significantly higher than those in M0 (Table 5), which indicates that straw mulching could significantly improve maize yield and yield components when compared with the no mulching treatment. In addition, the difference among M3, M4, and M5 was not significant; this indicates that when the straw mulching level increased to a certain level, the effect on maize yield and yield components of changing the straw mulching level was no longer significant.

\section{Correlation analysis}

Microbe quantity (bacteria, actinomycetes, fungi, and Azotobacter) and enzyme activities (urease, invertase, dehydrogenase, and protease) in soil, as well as chlorophyll content, photosynthetic rate, 1000-kernel weight, and yield of maize were all significantly and positively correlated with each other, and this indicates that the increase of soil microbe quantity had an important effect on enhancing soil enzyme activities, crop photosynthetic rate, and yield (Table 6). Table 6 also shows that the urease, invertase, dehydrogenase, and protease soil enzyme activities were all significantly correlated with chlorophyll content, photosynthetic rate, 1000-kernel weight, and yield of maize, indicating that the increase of soil enzyme activities also had an important impact on improving maize photosynthesis and yield. Therefore, the relationship between soil microbe quantity and enzyme activities may be fully exploited by an appropriate straw mulching level, and improving the soil micro-ecological environment is significantly important for improving photosynthesis and crop yield.

\section{DISCUSSION}

Compared to the treatment without mulching, straw mulching has many benefits to crop production (Stagnari et al., 2014). Yang et al. (2006) indicated that mulching had an apparent impact on crop chlorophyll content, and that straw mulching and plastic film mulching could help to increase crop chlorophyll content. In the present study, we not only found that chlorophyll content was the highest in M4 and the lowest in M0, but that the differences among M2, M3, M4, M5, and M6 were not significant; this indicates that straw mulching could significantly increase maize chlorophyll content when compared to the treatment without mulching, and the effects of straw mulching would decrease when the straw mulching level increased to a certain level. Sekhon et al. (2005) also found that straw mulching could significantly increase soybean chlorophyll content. Effectively improving

Table 5. Effects of different straw mulching levels on maize yield and yield components.

\begin{tabular}{|c|c|c|c|c|c|}
\hline $\begin{array}{l}\text { Mulching } \\
\text { treatment }\end{array}$ & Ear length & Ear diameter & Kernels per ear & $\begin{array}{l}\text { 1000-kernel } \\
\text { weight }\end{array}$ & Yield \\
\hline $\mathrm{kg} \mathrm{ha}^{-1}$ & 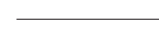 & - & & g & $\mathrm{kg} \mathrm{ha}^{-1}$ \\
\hline M0: 0 & $15.32 \pm 0.36 \mathrm{~d}$ & $4.08 \pm 0.07 \mathrm{~d}$ & $566.30 \pm 6.90 \mathrm{c}$ & $267.86 \pm 8.68 \mathrm{~d}$ & $9365.12 \pm 217.89 \mathrm{~d}$ \\
\hline M1: 3000 & $16.42 \pm 0.64 c$ & $4.19 \pm 0.06 \mathrm{~cd}$ & $575.24 \pm 12.07 \mathrm{bc}$ & $278.74 \pm 7.24 \mathrm{c}$ & $9687.64 \pm 218.22 \mathrm{c}$ \\
\hline M2: 6000 & $17.00 \pm 0.61 b c$ & $4.26 \pm 0.06 \mathrm{abc}$ & $581.86 \pm 11.23 \mathrm{ab}$ & $283.24 \pm 4.09 \mathrm{abc}$ & $9947.40 \pm 216.56 \mathrm{abc}$ \\
\hline M3: 9000 & $17.56 \pm 0.53 \mathrm{ab}$ & $4.32 \pm 0.08 \mathrm{ab}$ & $585.92 \pm 8.90 \mathrm{ab}$ & $288.98 \pm 6.79 \mathrm{ab}$ & $10063.78 \pm 227.96 a b$ \\
\hline M4: 12000 & $18.14 \pm 0.63 \mathrm{a}$ & $4.37 \pm 0.09 a$ & $588.68 \pm 9.13 \mathrm{a}$ & $291.76 \pm 5.64 a$ & $10186.84 \pm 221.31 \mathrm{a}$ \\
\hline M5: 15000 & $17.32 \pm 0.69 \mathrm{ab}$ & $4.28 \pm 0.10 \mathrm{abc}$ & $582.80 \pm 5.65 \mathrm{ab}$ & $286.54 \pm 7.05 \mathrm{abc}$ & $9950.38 \pm 240.95 a b c$ \\
\hline M6: 18000 & $16.72 \pm 1.09 \mathrm{bc}$ & $4.22 \pm 0.09 b c$ & $579.16 \pm 8.77 \mathrm{ab}$ & $281.72 \pm 7.35 b c$ & $9839.42 \pm 190.06 b c$ \\
\hline
\end{tabular}

Values are means $\pm \mathrm{SD}(\mathrm{n}=5)$. Means followed by different letters in the same column indicate a significant difference $(P<0.05)$.

Table 6. Correlation analyses between microbe quantity, enzyme activities, chlorophyll content, photosynthetic rate, 1000-kernel weight, and yield in maize.

\begin{tabular}{|c|c|c|c|c|c|c|c|c|c|c|c|}
\hline & 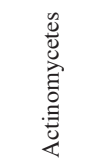 & 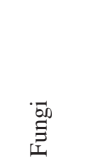 & $\begin{array}{l}1 \\
\vdots \\
0 \\
0 \\
0 \\
0 \\
0 \\
0 \\
0\end{array}$ & 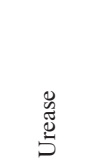 & 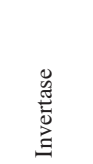 & 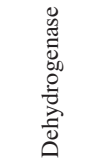 & 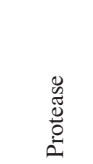 & 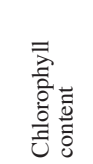 & 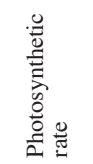 & 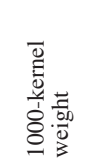 & $\frac{\nabla}{\stackrel{D}{~}}$ \\
\hline Bacteria & $0.983^{* *}$ & $0.965^{* *}$ & $0.929^{* *}$ & $0.844^{*}$ & $0.955^{* *}$ & $0.944^{* * *}$ & $0.957^{* * *}$ & $0.941^{* *}$ & $0.939^{* *}$ & $0.940^{* * *}$ & $0.943^{* *}$ \\
\hline Actinomycetes & & $0.978^{* *}$ & $0.964^{* *}$ & $0.896^{* *}$ & $0.988^{* *}$ & $0.951^{* *}$ & $0.964^{* * *}$ & $0.966^{* *}$ & $0.939^{* * *}$ & $0.953^{* *}$ & $0.944^{* *}$ \\
\hline Fungi & & & $0.989^{* *}$ & $0.949^{* *}$ & $0.986^{* *}$ & $0.986^{* *}$ & $0.989^{* * *}$ & $0.993^{* *}$ & $0.982^{* *}$ & $0.981^{* *}$ & $0.977^{* *}$ \\
\hline Azotobacter & & & & $0.958^{* *}$ & $0.987^{* *}$ & $0.973^{* *}$ & $0.978^{* * *}$ & $0.998^{* *}$ & $0.966^{* *}$ & $0.969^{* *}$ & $0.962^{* *}$ \\
\hline Urease & & & & & $0.933^{* * *}$ & $0.943^{* *}$ & $0.931^{* *}$ & $0.950^{* *}$ & $0.939^{* * *}$ & $0.949^{* * *}$ & $0.918^{* *}$ \\
\hline Invertase & & & & & & $0.963^{* *}$ & $0.972^{* *}$ & $0.988^{* * *}$ & $0.950^{* * *}$ & $0.962^{* * *}$ & $0.957^{* *}$ \\
\hline Dehydrogenase & & & & & & & $0.998^{* * *}$ & $0.982^{* *}$ & $0.998^{* *}$ & $0.997^{* *}$ & $0.996^{* *}$ \\
\hline Protease & & & & & & & & $0.987^{* *}$ & $0.995^{* * *}$ & $0.994^{* * *}$ & $0.995^{* *}$ \\
\hline Chlorophyll content & & & & & & & & & $0.976^{* *}$ & $0.976^{* *}$ & $0.975^{* *}$ \\
\hline Photosynthetic rate & & & & & & & & & & $0.994^{* *}$ & $0.993^{* *}$ \\
\hline 1000-kernel weight & & & & & & & & & & & $0.990^{* *}$ \\
\hline
\end{tabular}

${ }^{*} P<0.05 ;{ }^{* *} P<0.01$. 
leaf photosynthetic characteristics is an important way to increase crop yield. Zhang et al. (2008) indicated that wheat straw mulching significantly increased rice photosynthetic rate under non-flooded conditions. Thakur et al. (2000) also indicated by an experiment that mulched plants could maintain a higher leaf photosynthetic rate than unmulched plants at all water deficit levels. In the present study, we found that the photosynthetic rate, stomatal conductance, and transpiration rate of maize in M4 (highest value) were higher than in M0 and M6, and the difference between M4 and M0 was significant; this indicates that the suitable straw mulching level significantly improved the photosynthetic characteristics of maize, but when the straw mulching level was too high or too low, it would not be conducive to improving photosynthetic characteristics. Straw mulching can enhance maize chlorophyll content and photosynthetic rate mainly because straw mulching not only improves the soil physical and chemical characteristics in the maize rhizosphere (such as soil water content, heat energy, bulk density, and nutrient status), but also improves crop growth and development (Döring et al., 2005; BlancoCanqui and Lal, 2007; Chakraborty et al., 2008).

Soil microbe quantity and enzyme activities are sensitive biosensors of environmental changes, which have been widely used to measure and evaluate the effects of different agricultural measures on soil quality (Anderson et al., 2011; Zhang et al., 2013). Tu et al. (2006) found that straw mulching could enhance soil microbial biomass and activity when compared with the unmulched treatment. In the present study, we found that even a lower straw mulching level could have a significant effect on soil microbe quantity, and the microbe quantity in maize rhizosphere soil exhibited a trend change where it first increased and then decreased with increasing straw mulching levels. The reason why straw mulching increased soil microbe quantity may be because straw mulching buffered the extreme fluctuations in soil moisture and temperature (Ghosh et al., 2006; Tu et al., 2006) or straw mulching also improved crop root growth and increased the type and amount of root exudates, thus providing more $\mathrm{C}$ sources and energy for soil microorganisms. Our study also proved that the most suitable straw mulching levels for soil bacteria, actinomycetes, fungi, and Azotobacter were different. Studies of soil enzyme activities are important as they indicate the soil's potential to support biochemical processes that are essential for the maintenance of soil fertility and quality (Zhang et al., 2013). In the present study, we not only found that a suitable straw mulching level significantly enhanced soil enzyme activities, but that urease activity in M5, invertase activity in M3, and dehydrogenase and protease activity in M4 were the highest, respectively. Deng and Tabatabai (1996) also reported in their study that straw mulching could apparently increase soil enzyme activities when compared with the no mulching treatment. The reason why straw mulching increased soil enzyme activities is mainly because soil enzyme activities were evidently affected by soil physical, chemical, and biological characteristics (Jin et al., 2009), and the abovementioned soil properties could be effectively improved by a suitable straw mulching level (Deng and Tabatabai, 1996; Jin et al., 2009). Our study also proved that soil enzyme activities exhibited a trend change;they first increased and then decreased with increasing straw mulching levels; when the straw mulching level increased to a certain level, the difference in soil enzyme activities among different straw mulching levels was no longer apparent.

Shen et al. (2012) found that, under rainfed conditions in northern China, straw mulching could significantly enhance the grain yield of summer maize. In this study we found that straw mulching significantly increased maize yield and improved yield components when compared with the no mulching treatment, and ear length, ear diameter, kernels per ear, 1000-kernel weight, and yield of maize were the highest in M4. We also proved that a straw mulching level that was too high would not be conducive to improving maize yield and yield components. The potential mechanism of straw mulching can help to improve maize yield and yield components because it can effectively improve soil nutrient availability, increase plant growth (Fang et al., 2011), and influence soil physical and chemical properties (Jin et al., 2009). Correlation analysis indicated that the microbe quantity (bacteria, actinomycetes, fungi, and Azotobacter) and enzyme activities (urease, invertase, dehydrogenase, and protease) in the soil were significantly and positively ( $p<$ 0.05 ) related to maize chlorophyll content, photosynthetic rate, 1000-kernel weight, and yield. This is mainly because soil microbe quantity and enzyme activities are closely related to plant growth, crop nutrient status, and soil quality and fertility (Anderson et al., 2011; Zhang et al., 2013); this therefore results in their being closely related to crop photosynthesis, yield and yield components. All data in the present study indicated that crop chlorophyll content, photosynthetic rate, and yield can be enhanced through improving the soil micro-ecological environment with a suitable straw mulching level.

\section{CONCLUSIONS}

We conclude that a suitable straw mulching level can significantly improve crop chlorophyll content, photosynthetic characteristics, yield, and rhizosphere soil micro-ecological environment, but when the straw mulching level increases to a certain level, its effect is no longer apparent or can even negatively influence crop improvement. The most suitable straw mulching level for maize chlorophyll content, photosynthetic rate, and yield is $12000 \mathrm{~kg} \mathrm{ha}^{-1}$, while the most suitable straw mulching levels $\left(9000,12000\right.$, or $\left.15000 \mathrm{~kg} \mathrm{ha}^{-1}\right)$ for soil microbe quantity and enzyme activities are different. Soil microbe 
quantity and enzyme activities are strongly linked to crop chlorophyll content, photosynthetic rate, and yield; how to effectively explore a way of improving the soil microecological environment by agricultural measures will be significant for improving crop photosynthesis and yield in the future.

\section{ACKNOWLEDGEMENTS}

This work was supported by the National Natural Science Foundation of China (31401328) and the Outstanding Youth Fund of Anhui Academy of Agricultural Sciences (14B0202).

\section{LITERATURE CITED}

Anderson, C.R., L.M. Condron, T.J. Clough, M. Fiers, A. Stewart, R.A. Hill, et al. 2011. Biochar induced soil microbial community change: implications for biogeochemical cycling of carbon, nitrogen and phosphorus. Pedobiologia 54:309-320.

Anten, N.P.R. 2005. Optimal photosynthetic characteristics of individual plants in vegetation stands and implications for species coexistence. Annals of Botany 95:495-506.

Blanco-Canqui, H., and R. Lal. 2007. Soil structure and organic carbon relationships following 10 years of wheat straw management in no-till. Soil and Tillage Research 95:240-254.

Caldwell, B.A. 2005. Enzyme activities as a component of soil biodiversity: a review. Pedobiologia 49:637-644.

Chakraborty, D., S. Nagarajan, P. Aggarwal, V.K. Gupta, R.K. Tomar, R.N. Garg, et al. 2008. Effect of mulching on soil and plant water status, and the growth and yield of wheat (Triticum aestivum L.) in a semi-arid environment. Agricultural Water Management 95:1323-1334

Deng, S.P., and M.A. Tabatabai. 1996. Effect of tillage and residue management on enzyme activities in soils. II. Glycosidases. Biology and Fertility of Soils 22:202-207.

Döring, T.F., M. Brandt, J. Hess, M.R. Finckh, and H. Saucke. 2005. Effects of straw mulch on soil nitrate dynamics, weeds, yield and soil erosion in organically grown potatoes. Field Crops Research 94:238-249.

Fang, S.Z., B.D. Xie, D. Liu, and J.J. Liu. 2011. Effects of mulching materials on nitrogen mineralization, nitrogen availability and poplar growth on degraded agricultural soil. New Forests 41:147-162.

Ghosh, P.K., D. Dayal, K.K. Bandyopadhyay, and M. Mohanty. 2006. Evaluation of straw and polythene mulch for enhancing productivity of irrigated summer groundnut. Field Crops Research 99:76-86.

Govaerts, B., K.D. Sayre, K. Lichter, L. Dendooven, and J. Deckers. 2007. Influence of permanent raised bed planting and residue management on physical and chemical soil quality in rain fed maize/wheat systems. Plant and Soil 291:39-54.

Guan, S., D. Zhang, and Z. Zhang. 1986. Soil enzyme and its research methods. Agriculture Press, Beijing, China (In Chinese).

Jin, K., S. Sleutel, D. Buchan, S. De Neve, D.X. Cai, D. Gabriëls, et al. 2009. Changes of soil enzyme activities under different tillage practices in the Chinese Loess Plateau. Soil and Tillage Research 104:115-120.
Lal, R. 2000. Mulching effects on soil physical quality of an Alfisol in western Nigeria. Land Degradation and Development $11: 383-392$

Li, R., X. Hou, Z. Jia, Q. Han, X. Ren, and B. Yang. 2013. Effects on soil temperature, moisture, and maize yield of cultivation with ridge and furrow mulching in the rainfed area of the Loess Plateau, China. Agricultural Water Management 116:101-109.

Makino, A. 2011. Photosynthesis, grain yield, and nitrogen utilization in rice and wheat. Plant Physiology 155:125-129.

Novak, M.D., W. Chen, and M.A. Hares. 2000. Simulating the radiation distribution within a barley-straw mulch. Agricultural and Forest Meteorology 102:173-186.

Rillig, M.C., and D.L. Mummey. 2006. Mycorrhizas and soil structure. New Phytologist 171:41-53.

Sekhon, N.K., G.S. Hira, A.S. Sidhu, and S.S. Thind. 2005. Response of soybean (Glycine max Mer.) to wheat straw mulching in different cropping seasons. Soil Use and Management 21:422-426.

Shen, J.Y., D.D. Zhao, H.F. Han, X.B. Zhou, and Q.Q. Li. 2012. Effects of straw mulching on water consumption characteristics and yield of different types of summer maize plants. Plant, Soil and Environment 58:161-166.

Smith, S.E., and D.J. Read. 2008. Mycorrhizal symbiosis, $3^{\text {rd }}$ ed. Academic Press, New York, USA

Stagnari, F., A. Galieni, S. Speca, G. Cafiero, and M. Pisante. 2014. Effects of straw mulch on growth and yield of durum wheat during transition to Conservation Agriculture in Mediterranean environment. Field Crops Research 167:51-63.

Tan, X., S.X. Chang, and R. Kabzems. 2008. Soil compaction and forest floor removal reduced microbial biomass and enzyme activities in a boreal aspen forest soil. Biology and Fertility of Soils 44:471-479.

Thakur, P.S., A. Thakur, and S.P. Kanaujia. 2000. Reversal of water stress effects. I. Mulching impact on the performance of Capsicum аппиит under water deficit. Indian Journal of Horticulture $57: 250-254$

Tu, C., J.B. Ristaino, and S. Hu. 2006. Soil microbial biomass and activity in organic tomato farming systems: Effects of organic inputs and straw mulching. Soil Biology and Biochemistry $38: 247-255$

Van der Heijden, M.G.A., R.D. Bardgett, and N.M. van Straalen. 2008. The unseen majority: soil microbes as drivers of plant diversity and productivity in terrestrial ecosystems. Ecology Letters 11:296-310.

Vieira, F.C.S., and E. Nahas. 2005. Comparison of microbial numbers in soils by using various culture media and temperatures. Microbiological Research 160:197-202

Yang, Y.M., X.J. Liu, W.Q. Li, and C.Z. Li. 2006. Effect of different mulch materials on winter wheat production in desalinized soil in Heilonggang region of North China. Journal of Zhejiang University Science B 7:858-867.

Zhang, X., G. Huang, X. Bian, and Q. Zhao. 2013. Effects of nitrogen fertilization and root interaction on the agronomic traits of intercropped maize, and the quantity of microorganisms and activity of enzymes in the rhizosphere. Plant and Soil 368:407-417.

Zhang, Z., S. Zhang, J. Yang, and J. Zhang. 2008. Yield, grain quality and water use efficiency of rice under non-flooded mulching cultivation. Field Crops Research 108:71-81. 